\title{
Gender and Age Inequalities: Employment, Promotion and Retirement in Public Service Sectors of China
}

\author{
Cui Wantian Wang Dan \\ Economic Department in Liaoning University \\ Institute of China's Economic Reform \&Development in Renmin University of China
}

\begin{abstract}
This paper reviews the evolution and progress of the Chinese gender and age legal system since 1949, and further conducts labor market analyses on the basis of gender and age. This paper attempts to answer three questions, first, to offer reflections on the characteristics and social effects of gender and age inequalities on employment, promotion and retirement in public service sectors of China; second, to examine the social gender and age inequalities by data description; third, to suggest realistic solutions and feasible paths for achieving gender and age equalities in employment, promotion, and retirement in public service sectors of China.
\end{abstract}

Keywords: gender inequalities in China , age discrimination in China, paths for achieving equality

1. The gender and age discrimination phenomenon that exist in China's public services sector

\subsection{Gender discrimination}

Although the Civil Service Law avoids the specific provisions of the retirement age for men and women, in practice, the civil servants' retirement ages for men and women are still not equal. For men 60 , and for women 55 . For women civil servants, as their retirement age can not be the same as that of men, it not only indicates unequal treatment, but also means that the practices of female participation in politics have been shortened by five years. Moreover, considering the number of female government officials; the small proportion of woman representatives in People's Congress is obvious: in the Chinese Yearbook of Labor Statistics in 2003, and the gender constitution of workers and remuneration statistics show that female employment ratio in government offices, political parties, and social groups is just 25.24 percent, the gender discrimination appears more often in elections, recruitment practices in hidden ways.

\subsection{Age discrimination}

There are two manifestation of age discrimination in China: lowest and highest limit in age. The age discrimination in public employment has the lowest and highest regulations. Generally speaking, the lowest limit is above 18 , this is a qualification regulation to the government employees who want to perform the rights of government. The highest limit is reflected in interview, promotion, and retirement practices. For example, the second requirement for application in "Central and State Civil Servants Recruitment Notice in 2006" regulates: people who apply for non- 
leadership positions below director and section officer are require to be between 18-35 years old (born from October 10th, of 1969 to October 5th, of 1987 ). The seventh article in "Party and Government Preparatory Leaders Articles" regulates: Preparatory leaders on provincial level should be mostly 45 to 50 years old. There should be 1 or 2 leaders younger than 45 at the ministry level, and 3 to 5 at the provincial level, autonomous regions, and independently administered municipal districts. For example, in the eighteenth political bureau standing committee $\mathrm{Hu}$ Chunhua and Sun Zhengcai who were born in 1960s as the youngest member entered the party and state leader. This is a sign that they as the sixth generation identity have been officially confirmed. And there are 7 other younger members, $\mathrm{Lu} \mathrm{Hao}, \mathrm{Su}$ Shulin etc. who were born in 1960s also take provincial level or other important position in the bureau committee and will enter the core power institution, central political bureau in the future.

\section{Prima facie evidence of the gender and age discrimination in China}

China's public service sector is characterized by high participation rates among old and young, men and women, and this high participation rates are listed as follow. Generally speaking, before proceeding to the formal empirical analyses, it is helpful to review what the gender and age discrimination looked likbve before during the sample period. This date as follow will provide a first look of the gender and age discrimination in china. The main aspects of Prima facie evidence are listed as follow (Some specific data, see Appendix part)

(1) The gender difference of Laid-off workers and gender discrimination in the recruitment (Table 1 -Table 3 )
(2) The gender gap of social security and income began to take shape and expand (Table 4-Table 6)

As a preliminary research, the above facts and data are far from being enough. The collection of facts and data on this issue in itself is a step forward in gender and age equality. To do research in subsequent theory and practice, there are numerous relevant tasks to be done.

\section{Realistic and Feasible Path to achieve Gender and Age equity}

The author believes that there are at least three ways in terms of realistic conditions and feasible paths to eliminate gender and age discrimination: first, change the current conditions of gender and age discrimination in public service sectors and correct related biases on the basis of the 6 principles. , And build up the value system with human equality, liberty and development as priority order in the core; second, by means of reform and innovation in law and institution, change existing management and evaluation system of gender and age, build a new institutional system ensuring gender and age equality, promote market-orientation and democratic participation incentive measures, and increase information transparency and equal selection mechanism; third, transform the current economic growth model, improve quality of economic development, intensify training and education processes, enhance possibility of freedom of choice, and seek reform in stable society.

There are two ways to perfect antidiscrimination law in public service sectors, one is to modify existing laws and regulations, the other is to put employees in public service sectors into a general employment framework, and into the field of anti-discrimination. Increase regulations on different types of discrimination, to increase individual 
protection. Establish supervision mechanism on regulations. The best way is to establish systematic violation supervision system. It is advisable to set up a constitutional committee under National People's Congress to supervise the constitution. Perfection of the legal procedures is a relief to discrimination in non-elected public service sectors. Establish a human resource incentive system reflecting human comprehensive information and capability, to ensure equality in gender and age, including equality in recruitment, transfer and retirement.

As a research vision, it contains many possibilities, certainly some imperfect parts. However, if this paper can contribute to freeing Chinese citizens from the invisible chains in the aspect of gender and age discrimination, the author is willing to confront and undertake such risks.

\section{References}

[1] Adams,2004 S. Adams, Age discrimination legislation and the employment of older workers, Labour Economics 11 (2004), pp. 219-241.

[2] Becker, 1993 G.S. Becker, Human Capital, University of Chicago Press, Chicago (1993).

[3] Cook,(2005) Gender equality policy and practice in employment and mangement in cooke,F HRM,Work and Employment in china ,London Routledge,pp113-132

[4] De Schutter,2008 O. De Schutter, Homophobia and Discrimination on
Grounds of Sexual Orientation in the EU Members States: Part I, Legal Analysis, European Union Agency for Fundamental Rights (2008).

[5] Edwads,(2004) Edwads, Women's political word and women's in Mclaren,A (2004) Chinese Womenliving and working,London, Routledge,pp.110-128

[6] Liu ji tong ,(2003). Liu ji tong The brink of economic and social exclusion: the experience of female employment survey which is based on community enterprises in Guangzhou City, the social exclusion and marginal in Chinese community ,

Hong Kong:The Applied Social Sciences Center for Policy Research of the Hong Kong Polytechnic University (2003)

[7] Lazear, E.P., 1979. Why is there mandatory retirement?. Journal of Political Economy 87, pp. 1261-1284.

[8] Mueller, Mutran, \& Boyle,1989 C. Mueller, E. Mutran and E. Boyle, Age discrimination in earnings in a dual-economy market, Research on Aging 11 (4) (1989), pp. 492-507.

[9] Special Eurobarometer, 2007 Special Eurobarometer, Discrimination in the European Union, Wave 263 (2007) 65.4

[10] Shi tong,(2004). Shi tong Chinese social exclusion during the period of transformation- in the perspective of laid-off workers of state-owned enterprises, Beijing University Press (2004) 


\section{Appendix}

Table 1 Gender composition of unemployed youth by region in 1990 and 1995 Unite \%

\begin{tabular}{|c|c|c|c|c|}
\hline \multirow{2}{*}{ Region } & \multicolumn{2}{|c|}{$\begin{array}{l}\text { gender composition } \\
\text { in } 1990\end{array}$} & \multicolumn{2}{|c|}{$\begin{array}{c}\text { gender composition } \\
\text { in } 1995\end{array}$} \\
\hline & Female & Male & Female & Male \\
\hline Beijing & 45.5 & 54.5 & 66.7 & 33.3 \\
\hline Tianjin & 60.3 & 39.7 & 60.9 & 39.1 \\
\hline Hebei & 64.5 & 35.5 & 51.1 & 48.9 \\
\hline Shanxi & 61.8 & 38.2 & 62.0 & 38.0 \\
\hline $\begin{array}{c}\text { Inner } \\
\text { Mongolia }\end{array}$ & 57.9 & 42.1 & 60.8 & 39.2 \\
\hline Liaoning & 52.0 & 48.0 & 53.5 & 46.5 \\
\hline Jilin & 57.6 & 42.4 & 60.5 & 39.5 \\
\hline Heilongjiang & 59.0 & 41.0 & 68.4 & 31.6 \\
\hline Shanghai & 78.4 & 21.6 & 43.7 & 56.3 \\
\hline Jiangsu & 53.5 & 46.6 & 54.6 & 45.4 \\
\hline Zhejiang & 53.2 & 46.5 & 55.5 & 44.5 \\
\hline Anhui & 62.5 & 37.5 & 58.4 & 41.6 \\
\hline Fujian & 56.9 & 43.1 & 53.5 & 46.5 \\
\hline Jiangxi & 58.4 & 41.6 & 56.0 & 44.0 \\
\hline Shandong & 55.9 & 44.1 & 56.3 & 43.7 \\
\hline Henan & 59.0 & 41.0 & 57.7 & 42.3 \\
\hline Hubei & 56.6 & 43.4 & 57.5 & 42.5 \\
\hline Hunan & 59.4 & 40.6 & 60.0 & 40.0 \\
\hline Guangdong & 51.5 & 48.5 & 53.2 & 46.8 \\
\hline Guangxi & 59.0 & 41.0 & 61.7 & 38.3 \\
\hline Hainan & 48.3 & 51.7 & 48.2 & 51.8 \\
\hline \multicolumn{5}{|l|}{ Chongqing } \\
\hline Sichuan & 57.8 & 42.2 & 56.8 & 43.2 \\
\hline Guizhou & 60.6 & 39.1 & 60.3 & 39.7 \\
\hline Yunnan & 60.9 & 39.1 & 60.3 & 39.7 \\
\hline \multicolumn{5}{|l|}{ Tibet } \\
\hline Shaanxi & 61.4 & 38.4 & 59.7 & 40.3 \\
\hline Gansu & 58.9 & 41.1 & 55.8 & 44.2 \\
\hline Qinghai & 57.0 & 43.0 & 54.7 & 45.3 \\
\hline Ningxia & 60.9 & 39.1 & 57.5 & 42.5 \\
\hline Xinjiang & 64.6 & 35.4 & 61.3 & 38.7 \\
\hline Total & 58.0 & 42.0 & 57.4 & 42.6 \\
\hline
\end{tabular}

According to the 1991 and 1996 Statistical Yearbook of China's labor organize
Table 2 Age structure of employed persons and Unemployment rate in urban area in 2000

\begin{tabular}{|c|c|c|c|c|}
\hline \multirow{2}{*}{$\begin{array}{c}\text { Age } \\
\text { (year-old) }\end{array}$} & \multicolumn{2}{|c|}{ Age structure } & \multicolumn{2}{|c|}{$\begin{array}{c}\text { Unemployment Rate } \\
\text { (\%) }\end{array}$} \\
\hline & Female & Male & Female & Male \\
\hline $16-19$ & 13.4 & 15.8 & 17.8 & 25.9 \\
\hline $20-24$ & 21.1 & 19.8 & 12.8 & 13.1 \\
\hline $25-29$ & 18.1 & 14.3 & 9.1 & 6.7 \\
\hline $30-34$ & 15.3 & 13.1 & 7.7 & 5.8 \\
\hline $35-39$ & 14.2 & 12.9 & 8.0 & 6.4 \\
\hline $40-44$ & 10.9 & 10.5 & 8.5 & 6.9 \\
\hline $45-49$ & 6.1 & 8.0 & 6.1 & 5.8 \\
\hline $50-54$ & 0.8 & 4.1 & 2.0 & 4.7 \\
\hline $55-59$ & 0.2 & 1.3 & 0.9 & 2.8 \\
\hline $60-64$ & 0.1 & 0.2 & 0.8 & 0.8 \\
\hline $65+$ & 0.1 & 0.1 & 1.6 & 0.7 \\
\hline Total & 100.0 & 100.0 & 9.0 & 7.6 \\
\hline Population & 988 & 1079 & & \\
\hline
\end{tabular}

Source : ( Basic Statistics on National Population Census in 2000)

Table 3 Reasons of urban unemployment by sex units $\%$

\begin{tabular}{|c|c|c|c|c|c|c|c|}
\hline sex & $\begin{array}{c}\text { Did } \\
\text { not } \\
\text { work } \\
\text { after } \\
\text { gradu } \\
\text { ation }\end{array}$ & $\begin{array}{c}\text { The } \\
\text { origin } \\
\text { al } \\
\text { units } \\
\text { Bankr } \\
\text { uptcy }\end{array}$ & $\begin{array}{l}\text { Laid- } \\
\text { off or } \\
\text { retired } \\
\text { within }\end{array}$ & $\begin{array}{l}\text { Resig } \\
\text { nation }\end{array}$ & $\begin{array}{c}\text { By } \\
\text { resign } \\
\text { ated }\end{array}$ & $\begin{array}{c}\text { The } \\
\text { expira } \\
\text { tion } \\
\text { of the } \\
\text { contra } \\
\text { ct }\end{array}$ & Other \\
\hline Female & 21.9 & 13.2 & 34.0 & 6.1 & 2.4 & 5.4 & 17 \\
\hline Male & 17.2 & 15.4 & 37.4 & 6.7 & 2.3 & 6.1 & 14.5 \\
\hline
\end{tabular}

Source : According to the 2005Statistical Yearbook of China's labor organize 
Table 4 Gender differences in industry distribution and the number of years of education

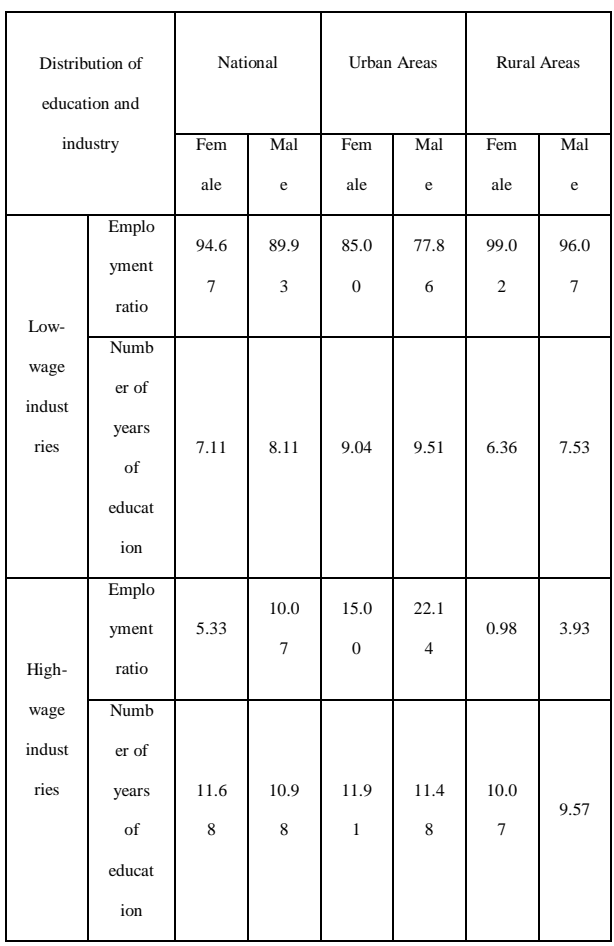

Source: Wang Meiyan: (China's urban labor market employment opportunities for men and women and the wage gap analysis )

Table 5 Average wage level of enterprises in 2002

\begin{tabular}{|l|c|c|c|}
\hline \multirow{2}{*}{ some sectors } & \multicolumn{2}{|c|}{ average wage (Yuan) } & \begin{tabular}{c} 
The average \\
wage for \\
\cline { 2 - 3 }
\end{tabular} \\
\cline { 2 - 3 } & Female & Male & $\begin{array}{c}\text { women is the } \\
\text { percentage of } \\
\text { the average }\end{array}$ \\
\hline
\end{tabular}

